\title{
BRINP3 wt Allele
}

National Cancer Institute

\section{Source}

National Cancer Institute. BRINP3 wt Allele. NCI Thesaurus. Code C142376.

Human BRINP3 wild-type allele is located in the vicinity of $1 \mathrm{q} 31.1$ and is approximately $381 \mathrm{~kb}$ in length. This allele, which encodes BMP/retinoic acid-inducible neural-specific protein 3, is involved in neuronal differentiation and cell cycle arrest. Aberrant expression of the gene may be associated with pituitary tumors, tongue squamous cell carcinomas, ulcerative colitis, and peri-implantitis. Hypermethylation of the gene may be a marker for gastric cancer. 